\title{
Gambaran Umum Trigona spp. di Kabupaten Luwu Utara Provinsi Sulawesi Selatan
}

\author{
Phika Ainnadya Hasan*1, Andi Gita Maulidyah ${ }^{2}$, Ahmad Baihaqi $^{3}$ \\ ${ }^{1}$ Program Studi Pendidikan Biologi, Universitas Sulawesi Barat \\ ${ }^{2}$ Program Studi Pendidikan Biologi, STKIP Pembangunan Indonesia \\ ${ }^{3}$ Yayasan KEHATI \\ e-mail: *11phikahasan@unsulbar.ac.id, ${ }^{2}$ gitamaulidyah@gmail.com, ${ }^{3}$ ahmad.baihaqi@kehati.or.id
}

\begin{abstract}
Abstrak
Lebah madu tidak bersengat (Trigona spp.)tersebar dibeberapa pulau di Indonesia, diantaranya Jawa, Kalimantan dan Sulawesi dengan beberapa spesies endemik. Penelitian ini bertujuan untukmemberikan gambaran umum mengenai lebah madu tidak bersengat Kabupaten Luwu Utara, Provinsi Sulawesi Selatan. Penelitian ini bersifat eksploratifyang dilakukan di tiga desa di Kabupaten Luwu Utara, yaitu Desa Sabbang, Desa Baebunta dan Desa Bone-bone. Hasil pengamatan menunjukanterdapat tiga jenis lebahtidak bersengat yang dominan, yaitu Trigona incisa, Trigona leviceps dan Trigona biroi. Terdapat perbedaan jenis pakan pada ketiga desa yang menyebabkan perbedaan warna sarang.
\end{abstract}

Kata kunci: Keanekaragaman hayati, Stingless bee, Trigona spp.

\section{PENDAHULUAN}

Sulawesi merupakan salah satu pulau di Indonesia yang terkenal dengan endemisitasnya. Lebih dari sembilan jenis lebah madu tidak bersengat yang terdapat di Indonesia (Trigona apicalis, T. melina, T. itama, T. leviceps, T. drescheri, T. terminate dan T. fuscibasis), terdapat satu jenis endemic di Sulawesi yaitu T. insica. Potensi pemanfaatan lebah ini tidak kalah dari lebah madu pada umumnya (Apis spp.). Selain karena lebah ini tidak memiliki sengat (stingless bee), lebah ini merupakan penghasil madu, propolis, bee wax dan bee pollen. Harga propolis mentah di pasar Indonesia mencapai Rp. 500.000 per kilogramnya, sedangkan kualitas madu dari lebah ini diyakini lebih baik daripada Apis spp. (Riyandoko dan Riendriasari 2016).

Pemanfaatan lebah madu tidak bersengat di Sulawesi Selatan telah dilakukan di beberapa kabupaten yaitu Jeneponto (11 kelompok tani), Palopo (12 kelompok tani), Luwu (2-5 kelompok tani), Luwu Utara (100 orang) dan Luwu Timur (50 orang) (Mahmud 2008). Meskipun telah memberikan dampak positif berupa peningkatan perekonomian masyarakat lokal, pemanfaatan lebah madu tidak bersengat di beberapa kabupaten tersebut masih dilakukan secara tradisional. Belum dilakukan pendataan mengenai jenis lebah dan jenis pakan. Padahal, jenis pakan merupakan faktor penting dalam pembudidayaan, sebab akan menentukan rasa madu yang dihasilkan (Fatmadkk. 2017; Riendriasari dan Krisnawati 2017). Guntoro (2013) juga melaporkan bahwa produktivitas pollen dan propolis Trigona lebih tinggi pada tanaman polikultur daripada monokultur. Oleh karena itu penelitian ini menjadi penting untuk dilakukan untuk memberikan data awal terhadap penelitian selanjutnya mengenai lebah madu tidak bersengat (Trigona spp.) di provinsi Sulawesi selatan.

\section{METODE PENELITIAN}

Pengamatan dilakukan pada 27 - 29 Juli 2018 di Desa Sabbang, Desa Baebunta dan Desa Bone-bone, Kabupaten Luwu Utara, Provinsi Sulawesi Selatan. Penelitian ini merupakan penelitian ekploratif yang menggunakan metode jelajah. Pengamatan meliputi jenis lebah tidak bersengat dan jenis pakan. Serangga penyerbuk yang belum diketahui jenisnya selanjutnya dikoleksi dan dilakukan preservasi menggunakan etanol $70 \%$, untuk selanjutnya di identifikasi. Identifikasi serangga penyerbuk merujuk pada Michener (2000). Analisis data keanekaragaman dilakukan secara deskriptif. 
Hasil pengamatan menunjukan bahwa terdapat tiga jenis lebah madu tidak bersengat yang terdapat di tiga desa di kabupaten luwu utara, sulawesi selatan. Tiga spesies tersebut adalah $T$. incisa, T. laeviceps dan $T$. biroi. Namun ketiganya menunjukan perbedaan dominansi. Trigona incisa dominan di Desa Baebunta dan Desa Sabbang Kabupaten Luwu Utara Sulawesi Barat. Sedangkan Trigona biroi dan Trigona laeviceps ditemukan di ketiga desa. Perbedaan ini diduga erat kaitannya dengan topografi dan kemampuan adaptasi Trigona. Trigona incisa lebih menyukai daerah ketinggian. Sedangkan Trigona biroi dan T. laeviceps memiliki adaptasi yang cukup luas, yakni mulai daratan rendah hingga tinggi. Kemampuan adaptasi $T$. biroi dan $T$. laeviceps pada ketinggian juga dilaporkan oleh Suriawanto (2016), yaitu 10-1200 mdpl.

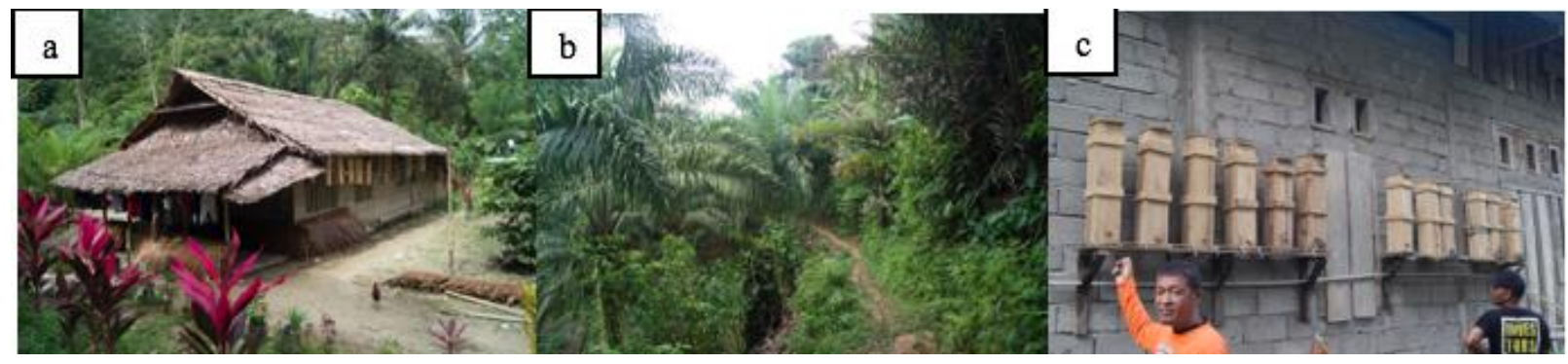

Gambar 1. Lokasi pengamatan a) Desa Sabbang, b) Desa Baebunta, c) Desa Bone-bone

Selain perbedaan ketinggian, juga terdapat perbedaan warna pintu masuk sarang (entrance). Pintu masuk sarang di Desa Bone-bone berwarna paling gelap, diikuti oleh Desa Sabbang dan Desa Baebunta. Perbedaan ini diduga disebabkan karena adanya perbedaan jenis pakan. Hal ini juga dilaporkan oleh Syafrizal, dkk. (2014) bahwa bentuk, warna, dan aroma pintu masuk sarang dipengaruhi oleh jenis tumbuhan sebagai sumber resinnya. Adapun jenis tumbuhan yang dijumpai pada setiap desa dapat dilihat pada tabel 1. Meskipun belum dilakukan penelitian lebih lanjut, namun dari hasil wawancara dengan peternak lebah setempat, bahwa nectar tanaman mangga (Mangifera indica) adalah penyebab mengapa warna pintu masuk sarang Desa Bonebone adalah yang paling gelap.

Tabel 1. Jenis tumbuhan di Desa Sabbang, Desa Baebunta dan Desa Bone-bone

\begin{tabular}{|l|c|c|c|}
\hline \multicolumn{1}{|c|}{ Jenis tumbuhan } & Desa Sabbang & Desa Baebunta & Desa Bone-bone \\
\hline Asoka (Saraca asoka) & $\mathrm{V}$ & $\mathrm{V}$ & $\mathrm{V}$ \\
\hline Mangga (Mangifera indica) & $\mathrm{V}$ & - & $\mathrm{V}$ \\
\hline Kelapa sawit (Elaeis guineensis) & $\mathrm{V}$ & $\mathrm{V}$ & - \\
\hline Vanili (Vanilla planifolia) & $\mathrm{V}$ & - & - \\
\hline Mengkudu (Morinda citrifolia) & - & - & $\mathrm{V}$ \\
\hline Rambutan (Nephelium lappaceum) & - & - & $\mathrm{V}$ \\
\hline Kedondong (Spondias dulcis) & - & - & $\mathrm{V}$ \\
\hline Coklat (Theobroma cacao) & - & - & $\mathrm{V}$ \\
\hline Langsat (Lansium domesticum) & - & $\mathrm{V}$ & - \\
\hline
\end{tabular}




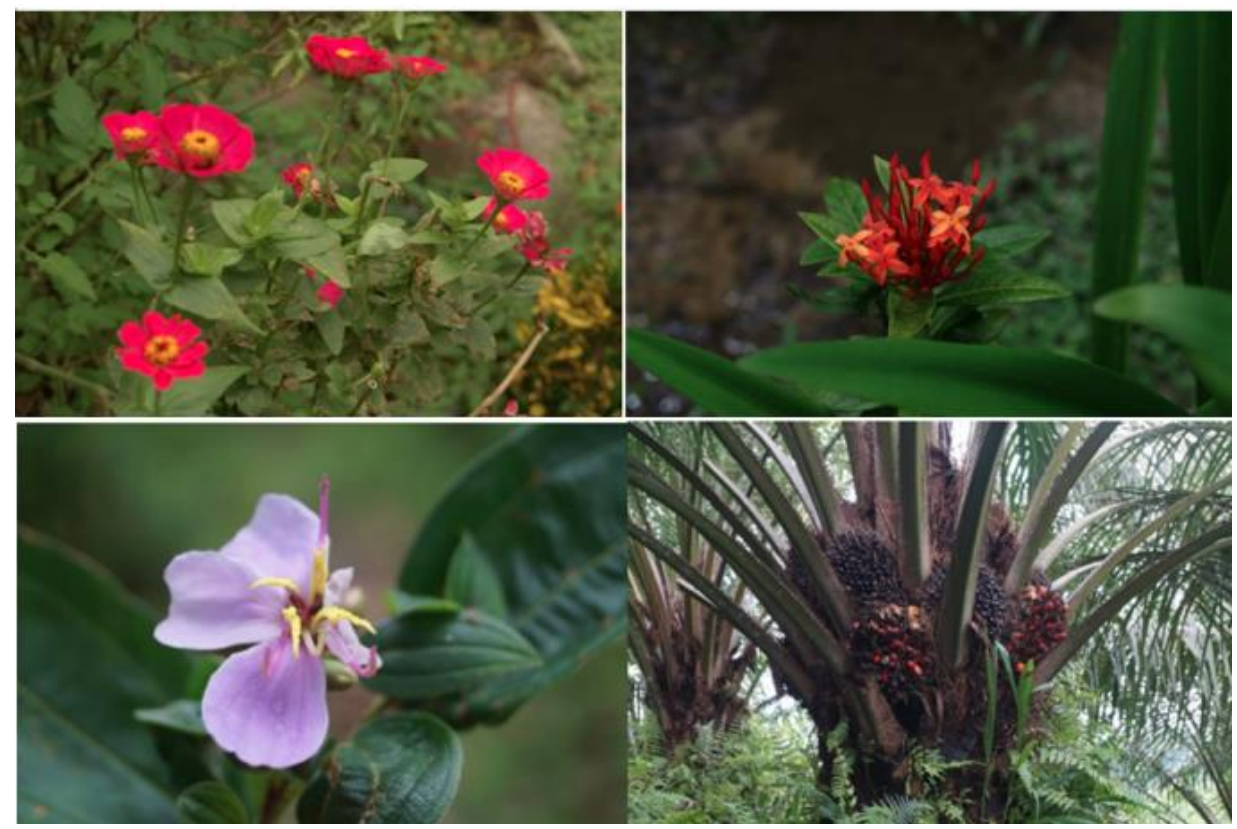

Gambar 2. Jenis tumbuhan di Desa Sabbang, Baebunta dan Bone-bone

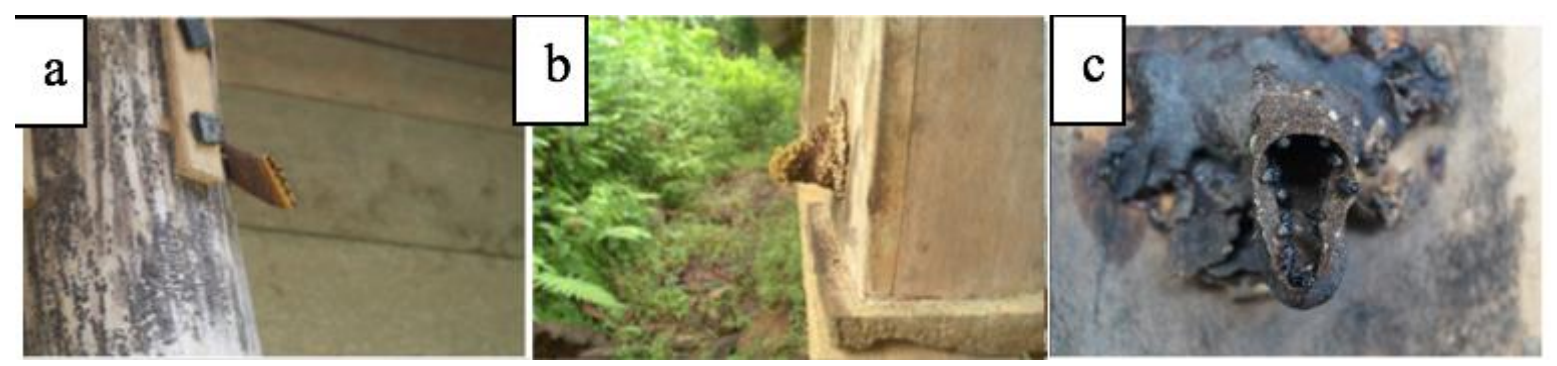

Gambar 3. Perbedaan warna pintu sarang a) Desa Sabbang, b) Desa Baebunta, dan c) Desa Bone-bone

\section{KESIMPULAN}

Terdapat tiga jenis lebah madu tidak bersengat (Trigona spp.) di tiga desa (Sabbang, Baebunta, dan Bone-bone) Kabupaten Luwu utara, Provinsi Sulawesi Selatan. Ketiganya yaitu Trigona incisa, Trigona biroi dan Trigona leviceps. Terdapat perbedaan dominansi diantara ketiga lebah tersebut, yang disebabkan oleh perbedaan topografi dan kemampuan adaptasi. Selain itu juga terdapat perbedaan waran pintu masuk (entrance) yang disebabkan oleh perbedaan jenis pakan.

\section{DAFTAR PUSTAKA}

Fatma II., Haryanti S., Suedy SWA., 2017. Uji Kualitas Madu pada beberapa Wilayah Budidaya Lebah Madu di Kabupaten Pati. Jurnal Biologi. 6(2):58-65.

Guntoro, YP., 2013. Aktivitas dan Produktivitas Lebah Trigona laeviceps di Kebun Polikultur dan Monokultur Pala (Myristica fragrans). Skripsi. Institut Pertanian Bogor.

Mahmud A., 2008. Pengembangan Lebah Madu dalam rangka Gerakan Pembangunan Masyarakat di Provinsi Sulawesi Selatan. Jurnal Hutan dan Masyarakat. 3(1):89-100.

Michener CD., 2007,The Bees of The World second edition, The Johns Hopkins University Press, Maryland.

Gambaran umum lebah madu tidak bersengat (trigona spp.) Di kabupaten luwu utara provinsi sulawesi selatan (Phika Ainnadya Hasan, dkk) 
https://jurnal.unsulbar.ac.id/index.php/saintifik

Riyandoko, Riendriasari SD., 2016. Memelihara Lebah Trigona: Panen Madu Tanpa Tersengat. Lembar Informasi Kanoppi.

Riendriasari SD., Krisnawati. 2017. Produksi Propolis Mentah Lebah Madu Trigona spp. di Pulau Lombok. $J$ Hut Trop. 1(1): 71-75.

Suriawanto, N., 2016. Keanekaragaman dan Tempat Bersarang Lebah Tak Bersengat (Hymenoptera: Apidae) di Sulawesi Tengah. Thesis. Instiut Pertanian Bogor.

Syafrizal, Taringan D., Yusuf R., 2014. Keragaman dan Habitat Lebah Trigona pada Hutan Sekunder Tropis Basah di Hutan Pendidikan Lempake, Samarinda, Kalimanatan Timur. Jurnal Teknologi Pertanian. 9(1):34-38 